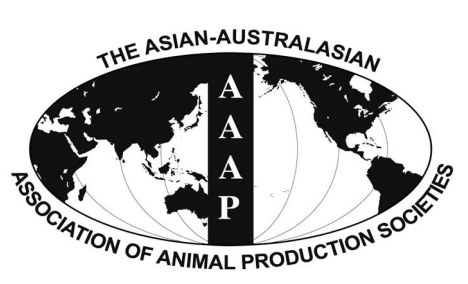

Open Access

Asian Australas. J. Anim. Sci.

Vol. 29, No. 8 : 1065-1074 August 2016

http://dx.doi.org/10.5713/ajas.15.0797

www.ajas.info

pISSN 1011-2367 elSSN 1976-5517

\title{
Role of Growth Differentiation Factor 9 and Bone Morphogenetic Protein 15 in Ovarian Function and Their Importance in Mammalian Female Fertility - A Review
}

\author{
Fernanda Cavallari de Castro*, Maria Helena Coelho Cruz, and Claudia Lima Verde Leal \\ Department of Veterinary Medicine, Faculty of Animal Science and Food Engineering, \\ University of São Paulo, Pirassununga, CEP 13635-900, Brazil
}

\begin{abstract}
Growth factors play an important role during early ovarian development and folliculogenesis, since they regulate the migration of germ cells to the gonadal ridge. They also act on follicle recruitment, proliferation/atresia of granulosa cells and theca, steroidogenesis, oocyte maturation, ovulation and luteinization. Among the growth factors, the growth differentiation factor 9 (GDF9) and the bone morphogenetic protein 15 (BMP15), belong to the transforming growth factor beta (TGF- $\beta$ ) superfamily, have been implicated as essential for follicular development. The GDF9 and BMP15 participate in the evolution of the primordial follicle to primary follicle and play an important role in the later stages of follicular development and maturation, increasing the steroidogenic acute regulatory protein expression, plasminogen activator and luteinizing hormone receptor (LHR). These factors are also involved in the interconnections between the oocyte and surrounding cumulus cells, where they regulate absorption of amino acids, glycolysis and biosynthesis of cholesterol cumulus cells. Even though the mode of action has not been fully established, in vitro observations indicate that the factors GDF9 and BMP15 stimulate the growth of ovarian follicles and proliferation of cumulus cells through the induction of mitosis in cells and granulosa and theca expression of genes linked to follicular maturation. Thus, seeking greater understanding of the action of these growth factors on the development of oocytes, the role of GDF9 and BMP15 in ovarian function is summarized in this brief review. (Key Words: Cumulus Cells, Granulosa Cells, Oocyte Maturation, Follicular Development, Reproductive Efficiency, TGF- $\beta$ Superfamily)
\end{abstract}

\section{INTRODUCTION}

The ovarian follicle is the functional unit of the ovary, in which the somatic components (thecal and granulosa cells), and germ (oocyte) are closely related and interdependent (Moenter et al., 1992; Aerts and Bols, 2010).

During oogenesis, the oocyte acquires cytoplasm and the molecular machinery required to support embryonic development in a process called oocyte training (Gilchrist et al., 2008; Sánchez and Smitz, 2012). However, the complete development of the oocyte within the follicular structure requires continuous two-way communication between the oocyte and cumulus cells that surround it

\footnotetext{
* Corresponding Author: Fernanda Cavallari de Castro. Tel: +55019-3565-4306, E-mail: nandacavallari@usp.br

Submitted Sept. 24, 2015; Revised Nov. 9, 2015; Accepted Dec. 23, 2015
}

(cumulus-oocyte complex), as well as other somatic cells included in the follicle, such as theca and the granulosa cells (Eppig et al., 2002; Gandolfi et al., 2005; Edson et al., 2009; Wigglesworth et al., 2013).

The granulosa cells are one of the constituents of the follicular environment of great importance for the acquisition of oocyte competence, ovulation and fertilization since they play roles in the production of steroids (estradiol and progesterone), expression of luteinizing hormone receptor (LHR), secretion of inhibin A and B (INHA and INHB), synthesis of numerous transcripts essential proteins, addition to the production and secretion of chemical factors necessary to maintain the oocyte in meiosis block (Richard and Sirard, 1996; Hatzirodos et al., 2014; Ceko et al., 2015). However, the functionality and action of these cells are dependent on some factors derived 
from the oocyte, capable of acting directly in the coordinated processes of follicular maturation through a paracrine signaling (Hutt and Albertini, 2007; Li et al., 2008b).

Among the factors secreted by the oocyte, we highlight members of the transforming growth factor beta (TGF- $\beta$ ) superfamily and, among these, the growth and differentiation factor 9 (GDF9) and bone morphogenetic protein 15 (BMP15), which are expressed in all stages of follicular development in the bovine species and are involved in controlling the proliferation and steroidogenesis of granulosa cells (Juengel and McNatty, 2005). These factors are essential for the activation of primordial follicles and subsequent follicular development and differentiation. Moreover, they are involved in the final stages of maturation and in the events prior to ovulation, for example, the expansion of the cumulus cells (Dong et al., 1996; Hanrahan et al., 2004; Yoshino et al., 2006; Su et al., 2008).

Growth factors GDF9 and BMP15 play a fundamental role in ovarian functioning and are essential for oocyte maturation processes, ovulation, fertilization and luteinization in mammals. Therefore this brief review aimed at grouping and summarizing the most relevant information about the role of these factors in ovarian functioning, seeking for a better understanding of their action in the development and oocyte maturation.

\section{Interaction between the oocyte, cumulus cells and granulosa cells}

Communication between the cumulus cells, the oocyte and granulosa occurs bi-directionally and is essential for the nuclear and cytoplasmic maturation processes and, consequently, for the acquisition of oocyte competence, fertilization and generation of an embryo with high development potential (Tanghe et al., 2002; Fair, 2003; Gandolfi et al., 2005; Gilchrist et al., 2008; Dias et al., 2014; Ceko et al., 2015). The cells of the granulosa and cumulus communicate with the oocyte by means of transzonal cytoplasmic processes, consisting of extensions of cumulus cells which penetrate through the zona pellucida and reach the oocyte membrane where an extensive group of transmembrane channels, known as gap junctions and gap communicating junctions, allows bidirectional transport of ions, metabolites, amino acids and small regulatory molecules (Anderson and Albertini, 1976; Albertini et al., 2001; Eppig et al., 2005; Hennet and Combelles, 2012). While the gap junctions allow the transfer of small molecular weight molecules between the cumulus cells and oocyte, large molecules are carried by receptor-mediated endocytosis. The interaction between the oocyte and the surrounding somatic cells may even occur through paracrine signaling (Sutton et al., 2003; Dias et al., 2014).
Methods of bidirectional communication between germ and somatic cells are essential for the spread of endocrine and paracrine signals that will act in the oocyte and cumulus cells in order to provide adequate competence to the oocyte (Orisaka et al., 2009). Communication between the granulosa cells and the oocyte is also crucial for folliculogenesis, oocyte maturation, and growth (Gilchrist et al., 2004). The benefits provided by the presence of these somatic cells during in vitro maturation can be attributed to the formation of a complex and favorable microenvironment (biochemical and metabolic) around the oocyte (Sutton et al., 2003; Hussein et al., 2006; Campos et al., 2011).

The oocytes, on the other hand, also have a crucial role in the regulation of cumulus and granulosa cells. From the production of paracrine factors, the oocyte is responsible for the modulation and proliferation of the function of granulosa cells, with a crucial role in the steroidogenesis process thereof (Vanderhyden and Tonary, 1995; Vanderhyden, 1996; Eppig et al., 1997, 1998; Gilchrist et al., 2006; Su et al., 2009; Young and McNeilly, 2010). The oocytes secrete substances that stimulate mitosis (oocytesecreted mitogens) of granulosa cells and cumulus and prevents their luteinization via soluble factors action (Gilchrist et al., 2008). Furthermore, the oocyte promotes the expression of anti-apoptotic proteins $\mathrm{Bcl}-2$ and suppresses pro-apoptotic protein Bax in granulosa cells and cumulus. Furthermore, the greater the distance of granulosa cells in relation to the oocyte, the greater the index of apoptosis of these cells, which proves the protective role of the factors secreted by the oocyte (Hussein et al., 2005; Campos et al., 2011).

The factors produced and secreted by the oocyte regulate folliculogenesis through modulation of cell growth and differentiation, besides having mitogenic action, and interact with the somatic cells regulating hormones such as follicle-stimulating hormone (FSH), growth factor similar to insulin-I and androgens (Armstrong et al., 1996; Hickey et al., 2004). Among the various growth factors produced by the oocyte and propagated to granulosa cells, we highlight the members of the superfamily of TGF- $\beta$ (Webb et al., 2003; Araújo et al., 2010; Fair, 2013). The TGF- $\beta$ superfamily is the largest family of protein secretors in mammals (Peng et al., 2013). Among the members of this superfamily, GDF9 and BMP15, secreted by the oocyte, are important regulators of cellular functions such as proliferation, differentiation, steroidogenesis, apoptosis and expansion of cumulus in addition to significantly improving oocyte developmental competence (Eppig, 2001; Matzuk et al., 2002; Gilchrist et al., 2004; Hussein et al., 2005). Such factors are capable of regulating female fertility in several species of mammals (Otsuka et al., 2011; Matzuk and Burns, 
2012).

\section{GDF9 and BMP15 factors and their importance on the ovarian function}

The major regulatory capacity of the oocyte on follicular growth and differentiation is achieved through the synthesis and secretion of specific factors in the oocyte, in particular of GDF9 and BMP15 paracrine factors belonging to the superfamily TGF- $\beta$, which act directly on the granulosa cells to modify their multiplication, function and differentiation, as well as through direct physical contact occurring in the oocyte granulosa-cell interface (Hutt and Albertini, 2007; Hennet and Combelles, 2012; Peng et al., 2013; Dias et al., 2014) .

The paracrine factors GDF9 and BMP15 have been the aim of numerous studies, which showed them to be essential to folliculogenesis and also for oocyte maturation and ovulation (Ying et al., 2000; Moore et al., 2004; Pangas and Matzuk, 2005; Su et al., 2008). The importance of GDF9 and BMP15 factors in the above processes is evidenced by reproductive defects in individuals that have mutations or deletion of these genes, as described in rats, mice, sheep, and humans (Galloway et al., 2000; Yan et al., 2001; Hanrahan et al., 2004; McNatty et al., 2004; Su et al., 2004; Peng et al., 2013) and by the ability of their recombinant forms to mimic the oocyte paracrine actions on granulosa cells and cumulus under in vitro conditions (Gilchrist et al., 2004). In human beings, mutations in GDF9 and BMP15 genes are associated with subfertility, higher incidence of dizygotic twins, damage to ovulation and even with ovarian failure in women (Dixit et al., 2006; Laissue et al., 2006; Hoekstra et al., 2008; Inagaki and Shimasaki, 2010). Therefore, altered or no expression of these factors may cause severe damage on ovarian function and fertility in several species of mammals (Juengel et al., 2004b; Moore et al., 2004; McNatty et al., 2005a, c; Gilchrist et al., 2008; Su et al., 2009; Otsuka et al., 2011).

The GDF9 and BMP15 factors, derived from the oocyte, were chosen as potential ligands to promote oocyte developmental competence during in vitro maturation, and can provide new opportunities in treatment of infertility (Peng et al., 2013).

Besides the folliculogenesis, oocyte capacitation and ovulation, GDF9 and BMP15 are still involved in the steroidogenesis, inhibition of luteinization and differentiation of cumulus and granulosa cells (Gilchrist et al., 2006; 2008; Su et al., 2008). Thus, folliculogenesis can be unregulated when one of these growth factors is absent or inactive (Dong et al., 1996; Carabatsos et al., 1998; Eppig, 2001; Gittens et al., 2005).

In most species of ruminants, ovarian GDF9 and BMP15 are exclusively expressed by the oocyte (Shimasaki et al., 2003; Juengel et al., 2004a; Araújo et al., 2010), although both have been detected by polymerase chain reaction in granulosa cells of antral follicles in goats (Silva et al., 2005).

The greatest number of investigations into the GDF9 gene occurred after the discovery that its deletion causes a blockage in the development of preantral follicles and consequently leads to infertility in mice (Dong et al., 1996). Mazerbourg and colleagues have found in 2004 that GDF9 is involved in the initial recruitment and in the progression of primordial follicles to the pre-antral stage (Mazerbourg et al., 2004). Thus, GDF9 is a cell growth and differentiation factor that acts in the somatic cells included in the follicle in a paracrine manner, where it stimulates changes in morphology, gene expression and production of steroids (Spicer et al., 2006; Paulini, 2010). The GDF9 still has an essential role in the growth and follicular atresia, ovulation, fertilization and reproduction in females (Elvin et al., 1999; Hayashi et al., 1999; Hanrahan et al., 2004; Juengel et al., 2004a; Orisaka et al., 2006; Palmer et al., 2006; Paulini, 2010).

The GDF9 was the first oocyte-specific factor that was shown to cause cumulus expansion, working as a oocyte paracrine action factor that regulates several key enzymes of granulosa cells important to the expansion of cumulus cells, proving the importance of this factor in creating an optimal microenvironment for the acquisition of oocyte developmental competence (Pangas and Matzuk, 2005; Gottardi and Mingoti, 2010). The inactivation of GDF9 gene in mouse oocytes culminated with the deficiency in the expansion of the cumulus-oocyte complex (Vanderhyden et al., 2003). Gui and Joyce (2005) completely eliminated the expansion of the cumulus cells, by inactivation of gene expression of GDF9 by RNA interference technique, leading to the conclusion that GDF9 in mice is the only permissive factor for the expansion of these cells (Gui and Joyce, 2005).

Expression of GDF9 is detectable from follicular development, primordial stage (in ruminants, [Bodensteiner et al., 1999]) or primary (in mice, [McGrath et al., 1995]) and is essential for the development of secondary follicles, since mice with deletion of this gene showed to be infertile and with follicular development interrupted at the primary stage (Dong et al., 1996; Silva et al., 2002; Buratini Jr, 2007; Mello et al., 2013). Furthermore, GDF9 stimulated preantral follicular growth in in vivo rats, probably by potentializing the proliferation of the granulosa cells (Vitt et al., 2000a, b).

In studies involving the shutdown of GDF9 expression, oocytes showed abnormal development and provision of cytoplasmic organelles and absence of apoptosis in granulosa cells (Shimasaki et al., 2004). In other studies 
about the inactivation GDF9, folliculogenesis was interrupted in the primary stage of development, resulting in the absence of formation of mature follicles, ovulations and, consequently, pregnancies (Dong et al., 1996; Elvin et al., 1999).

The GDF9, mostly expressed and secreted by the oocyte (Chang et al., 2002; Silva et al., 2009), has had its mRNA located in bovine, ovine (Bodensteiner et al., 1999) and caprine oocytes (Silva et al., 2004). The oocyte GDF9 besides regulating the growth and development of the follicle in all stages of folliculogenesis, also stimulates the expression of the FSH receptor (FSHR), protects cells against atresia, promotes cell proliferation, reduces LHR expression and affects the steroidogenesis of granulosa cells (Otsuka et al., 2011). The biological effect of GDF9 only occurs after its link to its specific receptor (Vitt et al., 2002; Mazerbourg et al., 2004).

The GDF9 also controls the expression of some genes in granulosa cells. The Gremlin protein had its expression increased by GDF9 in murine granulosa cells (Pangas et al., 2004) as well as INHB and steroidogenesis acute regulatory protein, which also had increased expression; while INHA had its expression decreased by GDF9 (Mazerbourg and Hsueh, 2006). Studies demonstrate that GDF9 also stimulates the basal secretion of progesterone and estradiol by the granulosa cells of small antral follicles of female rats (Vitt et al., 2000b).

Homologous to GDF9, the BMP15 has been found in oocytes of primordial and primary follicles of several species. As the GDF9, mRNA and proteins of the BMP15 gene are found in all oocytes during folliculogenesis, with increased expression levels in primary follicles to mature follicles of mice and rats (Paulini, 2010). The BMP15 protein was first observed in oocytes of primary follicles from sheep (Galloway et al., 2000), human (Aaltonen et al., 1999), rats (Jaatinen et al., 1999) and mice (Laitinen et al., 1998), and subsequently in primordial follicles of small marsupials (Eckery et al., 2002). In goats, the presence of BMP15 was shown in oocytes of all follicular categories as well as in granulosa cells from primary, secondary and antral follicles (Silva et al., 2005).

The BMP15 protein is produced and secreted by the oocyte, also known as GDF9B, and besides showing a significant mitogenic role over the granulosa cells, also contributes positively to follicular development during the initial and final stages of folliculogenesis (Otsuka et al., 2000; Juengel et al., 2004b; Lima et al., 2010). Papers using BMP15 have also checked their important role in the prevention of follicular atresia in somatic cells (Hussein et al., 2005; Yoshino et al., 2006).

The BMP15 mRNA expression, as well as GDF9, was not observed in oocytes prior to the formation of follicles being detected only in growing follicles, which indicated the function of these factors in the regulation of follicle development in mammals (Dube et al., 1998; Laitinen et al., 1998; Juengel and McNatty, 2005). Additional evidence of the participation of BMP15 in folliculogenesis, is that the proteins translated from this gene are released from the oocyte to the extracellular matrix oocyte-cumulus (Guéripel et al., 2006).

The BMP15 has been considered an important regulator of follicular development and ovulation in mammals (Galloway et al., 2000; Gilchrist et al., 2004; Juengel et al., 2004b; Shimasaki et al., 2004; McNatty et al., 2005b; Yeo et al., 2008; Hussein et al., 2011; Caixeta, 2012). Indeed, studies of passive immunization BMP15 revealed that immunized sheep showed reduced amount of follicles at stages superior to the primary stage and lower antrum formation and ovulation rate (Juengel et al., 2002). The BMP15 protein was still capable of stimulating the expression of epidermal growth factor in cumulus cells in mice (Yoshino et al., 2006).

The BMP15 has as its main target the granulosa cells and the stimulus of the proliferation of these cells and differential regulation of steroid hormones (Paulini, 2010). Thus, BMP15 is considered to be the main growth factor responsible for coordinating the proliferation of the granulosa cells and differentiation of normal reproductive physiology (Otsuka et al., 2011). GDF9 and BMP15 mRNA and their proteins may also be related to the expansion of cumulus cells, since they have increased their expressions at the time of this expansion (Li et al., 2008a, b).

Since BMP15 and GDF9 are secreted by the oocyte throughout the follicular growth, as evidenced in humans and sheep, it suggests that these two growth factors interact with each other, synergistically acting on target cells as a single functional complex (Juengel and McNatty, 2005; McNatty et al., 2005b; Otsuka et al., 2011; Juengel et al., 2013; Peng et al., 2013). One evidence of this interaction is that GDF9 inhibits the expression of ligand kit by granulosa cells, whereas BMP15 stimulates the expression (Gilchrist et al., 2008).

The member factors of the TGF- $\beta$ superfamily are synthesized within the endoplasmic reticulum as prepeptide precursors formed by the pro-region and the mature bioactive domain (Chang et al., 2002). The sequence of the constituent amino acids of the GDF9 factor contains four sites linked to glycosylation, one located in the mature region, while the BMP15 factor is provided with five glycosylation sites, two of these are located in the mature region (McGrath et al., 1995; Dube et al., 1998). In vitro studies performed with GDF9 and BMP15 factors demonstrate that glycosylation sites are critical for these factors recognition by their specific receptors, and therefore, for its bioactivity (Shimasaki et al., 2004).

In vitro experiments show that the physiological effect 
of GDF9 and BMP15 depends on the species in question, since the physiology and reproductive morphology between different species is very variable (McNatty et al., 2005b, c). However, many studies indicate that GDF9 and BMP15 have critical roles in ovarian architecture of most species and are essential factors for adequate follicular development, interfering considerably in the function, growth and formation of granulosa and theca cells during the growth of the follicle (Vitt and Hsueh, 2001; Otsuka et al., 2011). Therefore, mutations, inactivation or deletions in these genes are directly related with infertility, a fact that has received wide attention about these factors and their receptors in the scientific community (Elvin et al., 2000; McNatty et al., 2003; Di Pasquale et al., 2004; Shimasaki et al., 2004).

Overexpression of GDF9 and BMP15 factors in mouse oocytes can also lead to hipofertility in females with reduced offspring and long estrous cycles (Lan et al., 2003). Thus, maintaining precise levels of expression of GDF9 and BMP15 in oocytes, as well as their receptors in granulosa cells, is essential for adequate follicular development, increase fertility and improve reproductive efficiency in mammalian females (Peng et al., 2013).

\section{Specific receptors and signaling pathways of GDF9 and BMP15 factors}

The Smad proteins are part of a family of transcription factors found in vertebrates, insects and nematodes (Heldin et al., 1997; Huang et al., 2009), which are the only intracellular substrates of TGF- $\beta$ superfamily receptors. These proteins have the ability to propagate signals and are considered essential for the factors signaling members of the TGF- $\beta$ superfamily, including paracrine factors GDF9 and BMP15, derived from the oocyte (Heldin et al., 1997; Derynck, 1998; Peng et al., 2013).

The interaction that occurs between paracrine factors GDF9 and BMP15 and target cells, or somatic cells (granulosa and cumulus cells) that surrounds the oocyte, is performed via specific membrane receptors of the TGF- $\beta$ superfamily. These receptors are subdivided into two subclasses: type I receptors, includes seven receptors (ALK 1 to 7); and type II receptors, which comprise five receptors (Act RII, Act RIIB, AMHRII, TGF-ßRII, and BMPRII) (Miyazawa et al., 2002; Zhao et al., 2007; Paulini, 2010).

To act in adjacent cells to the oocyte, the GDF9 binds to the TGF- $\beta$ receptor type I (ALK5) (Moore et al., 2003; Mazerbourg et al., 2004; Huang et al., 2009) and BMPRII (Vitt et al., 2002), while the BMP15 binds to BMP receptor type IB (ALK6) and to the BMPRII (Peng et al., 2013). When attached to their specific ligands, they act as growth factors sets, bringing up two type I receptors and two type II receptors in a heteromeric complex (Franzén et al., 1993). In this complex, the type II receptors (BMPRII) perform the function of activating the type I receptors (ALK5 and ALK6) by phosphorylation of an intercellular regulatory region. The type I receptor, once activated, phosphorylates specific Smad proteins that, in turn, propagate the signal to the cell nucleus (Paulini, 2010; Peng et al., 2013). The specific Smad proteins (R-Smad), activated by the phosphorylation of two receptors type I, include Smads 1, 2, 3, 5, and 8. Once activated, Smad R-Smad molecules interact with another Smad molecule, called Smad 4, which consists of a common partner for all of the R-Smad, known as a common Smad (Smad-Co). This complex Smad/CoSmad (Smad4) is, finally, translocated to the cell nucleus to interact with specific transcription factors that regulate the expression of target genes (Nishimura et al., 1998; Gilchrist et al., 2008) (Figure 1).

The BMP15 paracrine factor uses a more classic way of signal transduction, joining to its BMPRII and ALK6 receptors and subsequently activating the Smads 1, 5, and 8 (Moore et al., 2003; Shimasaki et al., 2004; Li et al., 2009; Reader et al., 2011); while the GDF9 uses a signaling pathway via activin-TGF- $\beta$, binding to its BMPRII and ALK5 receptors and subsequently activating the Smads 2 and 3 (Vitt et al., 2002; Mazerbourg et al., 2004; Huang et al., 2009; Reader et al., 2011) (Figure 1).

Given the above, we can see that the type II receptor (BMPRII) has great importance for the adequate follicular development and acquisition of oocyte competence, besides being a common receptor for GDF9 and BMP15, it is still responsible for initiating a signaling cascade that comprises several events, starting from the phosphorylation and activation of the type I receptors. BMPRII, or receptor of bone morphogenetic protein type II, is expressed in the granulosa cells in the early stages of folliculogenesis in both ruminant primordial follicles as in preantral follicles in rodents, and continues to be expressed in all subsequent stages of follicular development (Juengel and McNatty, 2005; Lima, 2012).

\section{FINAL CONSIDERATIONS}

Within the follicular environment, there is a critical interaction between the oocyte and somatic cells surrounding it through continuous production and secretion of paracrine factors by the oocyte. The TGF- $\beta$ superfamily factors, in particular GDF9 and BMP15, play a critical role in ovarian architecture and fertility, being essential for the proper follicular growth and development, as well as for the formation, growth and function of granulosa and thecal cells. Such factors have as their main target the granulosa cells, and from their ability of functional modulation of these somatic cells, play a critical role in oocyte maturation and training process.

In this scenario, the GDF9 and BMP15 growth factors 


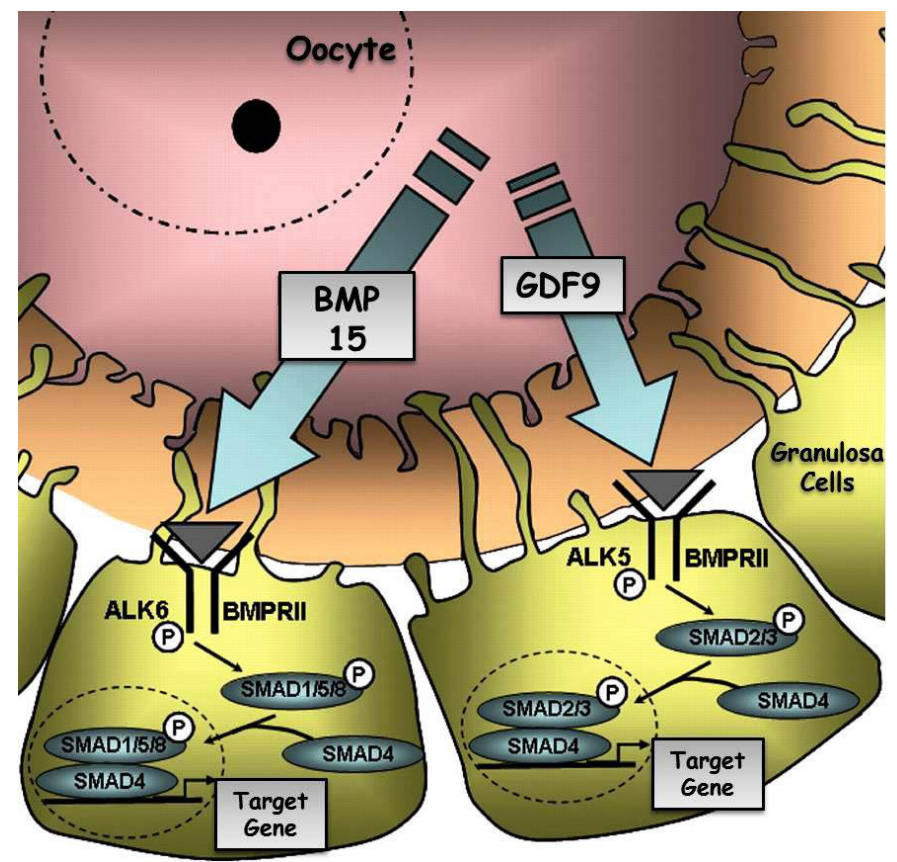

Figure 1. Schematic representation of paracrine signaling between the oocyte and the surrounding granulosa cells. The signaling pathways of growth differentiation factor-9 (GDF9) and bone morphogenetic protein 15 (BMP15) factors derived from the oocyte are depicted (adapted Gilchrist et al., 2008).

seem to be the regulating key of the ovarian organization and function, interfering considerably in oocyte development at all stages, in ovulation and hence in fertility of mammalian females. The depth and better understanding of these growth factors, becomes essential to optimize the reproductive biotechnologies, in particular maturation, fertilization and production of viable blastocysts in vitro.

\section{CONFLICT OF INTEREST}

We certify that there is no conflict of interest with any financial organization regarding the material discussed in the manuscript.

\section{ACKNOWLEDGMENTS}

This manuscript was supported by FAPESP (Fundação de Amparo à Pesquisa do Estado de São Paulo), grant number 2013/15374-3 to Cláudia Lima Verde Leal. Additional support was provided by $\mathrm{CNPq}$ (Conselho Nacional de Desenvolvimento Científico e Tecnológico), for a Masters scholarship to Fernanda Cavallari de Castro.

\section{REFERENCES}

Aaltonen, J., M. P. Laitinen, K. Vuojolainen, R. Jaatinen, N. Horelli-Kuitunen, L. Seppä, H. Louhio, T. Tuuri, J. Sjöberg, R. Bützow, O. Hovatta, L. Dale, and O. Ritvos. 1999. Human growth differentiation factor 9 (GDF-9) and its novel homolog GDF-9B are expressed in oocytes during early folliculogenesis.
J. Clin. Endocrinol. Metab. 84:2744-2750.

Aerts, J. M. J. and P. E. J. Bols. 2010. Ovarian follicular dynamics: A review with emphasis on the bovine species. Part I: Folliculogenesis and pre-antral follicle development. Reprod. Domest. Anim. 45:171-179.

Albertini, D. F., C. M. H. Combelles, E. Benecchi, and M. J. Carabatsos. 2001. Cellular basis for paracrine regulation of ovarian follicle development. Reproduction 121:647-653.

Anderson, E. and D. F. Albertini. 1976. Gap junctions between the oocyte and companion follicle cells in the mammalian ovary. J. Cell Biol. 71:680-686.

Araújo, V. R., A. P. Almeida, D. M. Magalhães, M. H. T. Matos, L. M. T. Tavares, J. R. Figueiredo, and A. P. R. Rodrigues. 2010. Role of Bone Morphogenetic Proteins-6 and -7 (BMP-6 and $7)$ in the regulation of early foliculogenesis in mammals. Rev. Bras. Reprodução Anim. 34:69-78.

Armstrong, D. T., P. Xia, G. Gannes, F. R. Tekpetey, and F. Khamsi. 1996. Differential effects of insulin-like growth factor-I and follicle-stimulating hormone on proliferation and differentiation of bovine cumulus cells and granulosa cells. Biol. Reprod. 54:331-338.

Bodensteiner, K. J., C. M. Clay, C. L. Moeller, and H. R. Sawyer. 1999. Molecular cloning of the ovine Growth/Differentiation factor-9 gene and expression of growth/differentiation factor-9 in ovine and bovine ovaries. Biol. Reprod. 60:381-386.

Buratini Jr, J. 2007. Endocrine and local control of folliculogenesis in cattle. Rev. Bras. Reprodução Anim. 31:190-196.

Caixeta, E. S. 2012. Regulation of Expression of Oocyte Secreted Factors (OSFs) and Their Receptors during Bovine In vitio Maturation (IVM) and Actions in the Control of Cumulus Expansion. Ph.D. Thesis, University of São Paulo State, Botucatu, São Paulo, Brazil.

Campos, C. O., A. A. Vireque, J. R. Campos, and A. C. J. S. R. 
Silva. 2011. The influence of interaction between oocyte and granulosa cells on the results of procedures in assisted reproduction. Femina 39:207-216.

Carabatsos, M. J., J. Elvin, M. M. Matzuk, and D. F. Albertini. 1998. Characterization of oocyte and follicle development in growth differentiation factor-9-deficient mice. Dev. Biol. 204:373-384.

Ceko, M. J., K. Hummitzsch, N. Hatzirodos, W. M. Bonner, J. B. Aitken, D. L. Russell, M. Lane, R. J. Rodgers, and H. H. Harris. 2015. X-Ray fluorescence imaging and other analyses identify selenium and GPX1 as important in female reproductive function. Metallomics 7:71-82.

Chang, H., C. W. Brown, and M. M. Matzuk. 2002. Genetic analysis of the mammalian transforming growth factor- $\beta$ superfamily. Endocr. Rev. 23:787-823.

Derynck, R. 1998. Developmental biology: SMAD proteins and mammalian anatomy. Nature 393:737-739.

Di Pasquale, E., P. Beck-Peccoz, and L. Persani. 2004. Hypergonadotropic ovarian failure associated with an inherited mutation of human bone morphogenetic protein-15 (BMP15) gene. Am. J. Hum. Genet. 75:106-111.

Dias, F. C. F., M. I. R. Khan, G. P. Adams, M. A. Sirard, and J. Singh. 2014. Granulosa cell function and oocyte competence: Super-follicles, super-moms and super-stimulation in cattle. Anim. Reprod. Sci. 149:80-89.

Dixit, H., L. K. Rao, V. V. Padmalatha, M. Kanakavalli, M. Deenadayal, N. Gupta, B. Chakrabarty, and L. Singh. 2006. Missense mutations in the $B M P 15$ gene are associated with ovarian failure. Hum. Genet. 119:408-415.

Dong, J., D. F. Albertini, K. Nishimori, T. R. Kumar, N. Lu, and M. M. Matzuk. 1996. Growth differentiation factor-9 is required during early ovarian folliculogenesis. Nature 383:531-535.

Dube, J. L., P. Wang, J. Elvin, K. M. Lyons, A. J. Celeste, and M. M. Matzuk. 1998. The bone morphogenetic protein 15 gene is $\mathrm{X}$-linked and expressed in oocytes. Mol. Endocrinol. (Baltimore, Md.). 12:1809-1817.

Eckery, D. C., L. J. Whale, S. B. Lawrence, K. A. Wylde, K. P. McNatty, and J. L. Juengel. 2002. Expression of mRNA encoding growth differentiation factor 9 and bone morphogenetic protein 15 during follicular formation and growth in a marsupial, the brushtail possum (Trichosurus vulpecula). Mol. Cell. Endocrinol. 192:115-126.

Edson, M. A., A. K. Nagaraja, and M. M. Matzuk. 2009. The mammalian ovary from genesis to revelation. Endocr. Rev. 30:624-712.

Elvin, J. A., C. Yan, and M. M. Matzuk. 2000. Oocyte-expressed TGF- $\beta$ superfamily members in female fertility. Mol. Cell. Endocrinol. 159:1-5.

Elvin, J. A., A. T. Clark, P. Wang, N. M. Wolfman, and M. M. Matzuk. 1999. Paracrine actions of growth differentiation factor-9 in the mammalian ovary. Mol. Endocrinol. (Baltimore, Md.). 13:1035-1048.

Eppig, J. J. 2001. Oocyte control of ovarian follicular development and function in mammals. Reproduction 122:829-838.

Eppig, J. J., K. Wigglesworth, and F. L. Pendola. 2002. The mammalian oocyte orchestrates the rate of ovarian follicular development. Proc. Natl. Acad. Sci. USA. 99:2890-2894.

Eppig, J. J., K. Wigglesworth, F. Pendola, and Y. Hirao. 1997.
Murine oocytes suppress expression of luteinizing hormone receptor messenger ribonucleic acid by granulosa cells. Biol. Reprod. 56:976-984.

Eppig, J. J., M. J. O’Brien, F. L. Pendola, and S. Watanabe. 1998. Factors affecting the developmental competence of mouse oocytes grown in vitro: Follicle-stimulating hormone and insulin. Biol. Reprod. 59:1445-1453.

Eppig, J. J., F. L. Pendola, K. Wigglesworth, and J. K. Pendola. 2005. Mouse oocytes regulate metabolic cooperativity between granulosa cells and oocytes: Amino acid transport. Biol. Reprod. 73:351-357.

Fair, T. 2003. Follicular oocyte growth and acquisition of developmental competence. Anim. Reprod. Sci. 78:203-216.

Fair, T. 2013. Molecular and endocrine determinants of oocyte competence. Anim. Reprod. 10:277-282.

Franzén, P., P. ten Dijke, H. Ichijo, H. Yamashita, P. Schulz, C. H. Heldin, and K. Miyazono. 1993. Cloning of a TGF beta type I receptor that forms a heteromeric complex with the TGF beta type II receptor. Cell 75:681-692.

Galloway, S. M., K. P. McNatty, L. M. Cambridge, M. P. Laitinen, J. L. Juengel, T. S. Jokiranta, R. J. McLaren, K. Luiro, K. G. Dodds, G. W. Montgomery, A. E. Beattie, G. H. Davis, and O. Ritvos. 2000. Mutations in an oocyte-derived growth factor gene (BMP15) cause increased ovulation rate and infertility in a dosage-sensitive manner. Nat. Genet. 25:279-283.

Gandolfi, F., T. A. L. Brevini, F. Cillo, and S. Antonini. 2005. Cellular and molecular mechanisms regulating oocyte quality and the relevance for farm animal reproductive efficiency. Rev. Sci. Tech. 24:413-23.

Gilchrist, R. B., L. J. Ritter, and D. T. Armstrong. 2004. Oocytesomatic cell interactions during follicle development in mammals. Anim. Reprod. Sci. 82-83:431-446.

Gilchrist, R. B., M. Lane, and J. G. Thompson. 2008. Oocytesecreted factors: Regulators of cumulus cell function and oocyte quality. Hum. Reprod. Update 14:159-177.

Gilchrist, R. B., L. J. Ritter, S. Myllymaa, N. Kaivo-Oja, R. A. Dragovic, T. E. Hickey, O. Ritvos, and D. G. Mottershead. 2006. Molecular basis of oocyte-paracrine signalling that promotes granulosa cell proliferation. J. Cell Sci. 119:38113821.

Gittens, J. E. I., K. J. Barr, B. C. Vanderhyden, and G. M. Kidder. 2005. Interplay between paracrine signaling and gap junctional communication in ovarian follicles. J. Cell Sci. 118:113-122.

Gottardi, F. P. and G. Z. Mingoti. 2010. Bovine oocyte maturation and influence on subsequent embryonic developmental competence. Rev. Bras. Reprod. Anim. 33:82-94.

Guéripel, X., V. Brun, and A. Gougeon. 2006. Oocyte bone morphogenetic protein 15 , but not growth differentiation factor 9 , is increased during gonadotropin-induced follicular development in the immature mouse and is associated with cumulus oophorus expansion. Biol. Reprod. 75:836-843.

Gui, L.-M. and I. M. Joyce. 2005. RNA interference evidence that growth differentiation factor-9 mediates oocyte regulation of cumulus expansion in mice. Biol. Reprod. 72:195-199.

Hanrahan, J. P., S. M. Gregan, P. Mulsant, M. Mullen, G. H. Davis, R. Powell, and S. M. Galloway. 2004. Mutations in the genes for oocyte-derived growth factors GDF9 and BMP15 are associated with both increased ovulation rate and sterility in 
Cambridge and Belclare sheep (Ovis aries). Biol. Reprod. 70:900-909.

Hatzirodos, N., H. F. Irving-Rodgers, K. Hummitzsch, M. L. Harland, S. E. Morris, and R. J. Rodgers. 2014. Transcriptome profiling of granulosa cells of bovine ovarian follicles during growth from small to large antral sizes. BMC Genomics 15:24.

Hayashi, M., E. A. McGee, G. Min, C. Klein, U. M. Rose, M. Van Duin, and A. J. W. Hsueh. 1999. Recombinant growth differentiation factor-9 (GDF-9) enhances growth and differentiation of cultured early ovarian follicles. Endocrinology 140:1236-1244.

Heldin, C.-H., K. Miyazono, and P. ten Dijke. 1997. TGF-bold beta signalling from cell membrane to nucleus through SMAD proteins. Nature 390:465-471.

Hennet, M. L. and C. M. H. Combelles. 2012. The antral follicle: A microenvironment for oocyte differentiation. Int. J. Dev. Biol. 56:819-831.

Hickey, T. E., D. L. Marrocco, R. B. Gilchrist, R. J. Norman, and D. T. Armstrong. 2004. Interactions between androgen and growth factors in granulosa cell subtypes of porcine antral follicles. Biol. Reprod. 71:45-52.

Hoekstra, C., Z. Z. Zhao, C. B. Lambalk, G. Willemsen, N. G. Martin, D. I. Boomsma, and G. W. Montgomery. 2008. Dizygotic twinning. Hum. Reprod. Update 14:37-47.

Huang, Q., A. P. Cheung, Y. Zhang, H.-F. Huang, N. Auersperg, and P. C. K. Leung. 2009. Effects of growth differentiation factor 9 on cell cycle regulators and ERK42/44 in human granulosa cell proliferation. Am. J. Physiol. Endocrinol. Metab. 296:E1344-E1353.

Hussein, T. S., J. G. Thompson, and R. B. Gilchrist. 2006. Oocytesecreted factors enhance oocyte developmental competence. Dev. Biol. 296:514-521.

Hussein, T. S., M. L. Sutton-McDowall, R. B. Gilchrist, and J. G. Thompson. 2011. Temporal effects of exogenous oocytesecreted factors on bovine oocyte developmental competence during IVM. Reprod. Fertil. Dev. 23:576-584.

Hussein, T. S., D. A. Froiland, F. Amato, J. G. Thompson, and R. B. Gilchrist. 2005. Oocytes prevent cumulus cell apoptosis by maintaining a morphogenic paracrine gradient of bone morphogenetic proteins. J. Cell Sci. 118:5257-5268.

Hutt, K. J. and D. F. Albertini. 2007. An oocentric view of folliculogenesis and embryogenesis. Reprod. Biomed. Online 14:758-764.

Inagaki, K. and S. Shimasaki. 2010. Impaired production of BMP15 and GDF-9 mature proteins derived from proproteins WITH mutations in the proregion. Mol. Cell. Endocrinol. 328:1-7.

Jaatinen, R., M. P. Laitinen, K. Vuojolainen, J. Aaltonen, H. Louhio, K. Heikinheimo, E. Lehtonen, and O. Ritvos. 1999. Localization of growth differentiation factor-9 (GDF-9) mRNA and protein in rat ovaries and cDNA cloning of rat GDF-9 and its novel homolog GDF-9B. Mol. Cell. Endocrinol. 156:189193.

Juengel, J. L., K. J. Bodensteiner, D. A. Heath, N. L. Hudson, C. L. Moeller, P. Smith, S. M. Galloway, G. H. Davis, H. R. Sawyer, and K. P. McNatty. 2004a. Physiology of GDF9 and BMP15 signalling molecules. Anim. Reprod. Sci. 82-83:447-460.

Juengel, J. L., N. L. Hudson, D. A. Heath, P. Smith, K. L. Reader, S. B. Lawrence, A. R. O'Connell, M. P. E. Laitinen, M.
Cranfield, N. P. Groome, O. Ritvos, and K. P. McNatty. 2002. Growth differentiation factor 9 and bone morphogenetic protein 15 are essential for ovarian follicular development in sheep. Biol. Reprod. 67:1777-1789.

Juengel, J. L. and K. P. McNatty. 2005. The role of proteins of the transforming growth factor- $\beta$ superfamily in the intraovarian regulation of follicular development. Hum. Reprod. Update 11:144-161.

Juengel, J. L., G. H. Davis, and K. P. McNatty. 2013. Using sheep lines with mutations in single genes to better understand ovarian function. Reproduction 146:R111-R123.

Juengel, J. L., A. H. Bibby, K. L. Reader, S. Lun, L. D. Quirke, L. J. Haydon, and K. P. McNatty. 2004b. The role of transforming growth factor-beta (TGF-beta) during ovarian follicular development in sheep. Reprod. Biol. Endocrinol. 2:78.

Laissue, P., S. Christin-Maitre, P. Touraine, F. Kuttenn, O. Ritvos, K. Aittomaki, N. Bourcigaux, L. Jacquesson, P. Bouchard, R. Frydman, D. Dewailly, A. C. Reyss, L. Jeffery, A. Bachelot, N. Massin, M. Fellous, and R. A. Veitia. 2006. Mutations and sequence variants in GDF9 and BMP15 in patients with premature ovarian failure. Eur. J. Endocrinol. 154:739-744.

Laitinen, M., K. Vuojolainen, R. Jaatinen, I. Ketola, J. Aaltonen, E. Lehtonen, M. Heikinheimo, and O. Ritvos. 1998. A novel growth differentiation factor-9 (GDF-9) related factor is coexpressed with GDF-9 in mouse oocytes during folliculogenesis. Mech. Dev. 78:135-140.

Lan, Z. J., P. Gu, X. Xu, K. J. Jackson, F. J. DeMayo, B. W. O'Malley, and A. J. Cooney. 2003. GCNF-dependent repression of $B M P-15$ and $G D F-9$ mediates gamete regulation of female fertility. EMBO J. 22:4070-4081.

Li, H.-K., T.-Y. Kuo, H.-S. Yang, L.-R. Chen, S. S.-L. Li, and H.W. Huang. 2008a. Differential gene expression of bone morphogenetic protein 15 and growth differentiation factor 9 during in vitro maturation of porcine oocytes and early embryos. Anim. Reprod. Sci. 103:312-322.

Li, Q., L. J. McKenzie, and M. M. Matzuk. 2008b. Revisiting oocyte-somatic cell interactions: In search of novel intrafollicular predictors and regulators of oocyte developmental competence. Mol. Hum. Reprod. 14:673-678.

Li, Q., S. Rajanahally, M. A. Edson, and M. M. Matzuk. 2009. Stable expression and characterization of N-terminal tagged recombinant human bone morphogenetic protein 15. Mol. Hum. Reprod. 15:779-788.

Lima, I. M. T., J. R. Celestino, J. R. Figueiredo, and A. P. R. Rodrigues. 2010. Role of Bone Morphogenetic Protein 15 (BMP-15) and Kit Ligand (KL) in the regulation of folliculogenesis in mammalian. Rev. Bras. Reprodução Anim. 34:3-20.

Lima, R. S. 2012. The Role of Insulin-like Growth Factor-I on Germinal Vesicle Oocytes Exposed to Heat Shock. Masters Dissertation, University of São Paulo State, Campus of Botucatu, São Paulo, Brazil.

Matzuk, M. M. and K. H. Burns. 2012. Genetics of mammalian reproduction: Modeling the end of the germline. Annu. Rev. Physiol. 74:503-528.

Matzuk, M. M., K. H. Burns, M. M. Viveiros, and J. J. Eppig. 2002. Intercellular communication in the mammalian ovary: oocytes carry the conversation. Science 296:2178-2180.

Mazerbourg, S. and A. J. W. Hsueh. 2006. Genomic analyses 
facilitate identification of receptors and signalling pathways for growth differentiation factor 9 and related orphan bone morphogenetic protein/growth differentiation factor ligands. Hum. Reprod. Update 12:373-383.

Mazerbourg, S., C. Klein, J. Roh, N. Kaivo-Oja, D. G. Mottershead, O. Korchynskyi, O. Ritvos, and A. J. W. Hsueh. 2004. Growth differentiation factor-9 signaling is mediated by the type I receptor, activin receptor-like kinase 5. Mol. Endocrinol. 18:653-665.

McGrath, S. A., A. F. Esquela, and S. J. Lee. 1995. Oocytespecific expression of growth/differentiation factor-9. Mol. Endocrinol. 9:131-136.

McNatty, K. P., P. Smith, L. G. Moore, K. Reader, S. Lun, J. P. Hanrahan, N. P. Groome, M. Laitinen, O. Ritvos, and J. L. Juengel. 2005a. Oocyte-expressed genes affecting ovulation rate. Mol. Cell. Endocrinol. 234:57-66.

McNatty, K. P., S. M. Galloway, T. Wilson, P. Smith, N. L. Hudson, A. O'Connell, A. H. Bibby, D. A. Heath, G. H. Davis, J. P. Hanrahan, and J. L. Juengel. 2005b. Physiological effects of major genes affecting ovulation rate in sheep. Genet. Sel. Evol. 37:S25-38.

McNatty, K. P., L. G. Moore, N. L. Hudson, L. D. Quirke, S. B. Lawrence, K. Reader, J. P. Hanrahan, P. Smith, N. P. Groome, M. Laitinen, O. Ritvos, and J. L. Juengel. 2004. The oocyte and its role in regulating ovulation rate: A new paradigm in reproductive biology. Reproduction 128:379-386.

McNatty, K. P., J. L. Juengel, K. L. Reader, S. Lun, S. Myllymaa, S. B. Lawrence, A. Western, M. F. Meerassahib, D. G. Mottershead, N. P. Groome, O. Ritvos, and M. P. E. Laitinen. 2005c. Bone morphogenetic protein 15 and growth differentiation factor 9 co-operate to regulate granulosa cell function in ruminants. Reproduction 129:481-487.

McNatty, K. P., J. L. Juengel, T. Wilson, S. M. Galloway, G. H. Davis, N. L. Hudson, C. L. Moeller, M. Cranfield, K. L. Reader, M. P. Laitinen, N. P. Groome, H. R. Sawyer, and O. Ritvos. 2003. Oocyte-derived growth factors and ovulation rate in sheep. Reprod. Suppl. 61:339-351.

Mello, R. R. C., J. E. Ferreira, A. P. T. B. Silva, M. R. B. Mello, and H. B. Palhano. 2013. Initial follicular development in cattle. Rev. Bras. Reprod. Anim. 37:328-333.

Miyazawa, K., M. Shinozaki, T. Hara, T. Furuya, and K. Miyazono. 2002. Two major Smad pathways in TGF- $\beta$ superfamily signalling. Genes Cells 7:1191-1204.

Moenter, S. M., R. M. Brand, A. R. Midgley, and F. J. Karsch. 1992. Dynamics of gonadotropin-releasing hormone release during a pulse. Endocrinology 130:503-510.

Moore, R. K., F. Otsuka, and S. Shimasaki. 2003. Molecular basis of bone morphogenetic protein-15 signaling in granulosa cells. J. Biol. Chem. 278:304-310.

Moore, R. K., G. F. Erickson, and S. Shimasaki. 2004. Are BMP15 and GDF-9 primary determinants of ovulation quota in mammals? Trends Endocrinol. Metab. 15:356-361.

Nishimura, R., Y. Kato, D. Chen, S. E. Harris, G. R. Mundy, and T. Yoneda. 1998. Smad5 and DPC4 are key molecules in mediating BMP-2-induced osteoblastic differentiation of the pluripotent mesenchymal precursor cell line $\mathrm{C} 2 \mathrm{C} 12$. J. Biol. Chem. 273:1872-1879.

Orisaka, M., K. Tajima, B. K. Tsang, and F. Kotsuji. 2009. Oocytegranulosa-theca cell interactions during preantral follicular development. J. Ovarian Res. 2:2-9.

Orisaka, M., S. Orisaka, J.-Y. Jiang, J. Craig, Y. Wang, F. Kotsuji, and B. K. Tsang. 2006. Growth differentiation factor 9 is antiapoptotic during follicular development from preantral to early antral stage. Mol. Endocrinol. 20:2456-2468.

Otsuka, F., K. J. McTavish, and S. Shimasaki. 2011. Integral role of GDF-9 and BMP-15 in ovarian function. Mol. Reprod. Dev. 78:9-21.

Otsuka, F., Z. Yao, T. -H. Lee, S. Yamamoto, G. F. Erickson, and S. Shimasaki. 2000. Bone morphogenetic protein-15 identification of target cells and biological functions. J. Biol. Chem. 275:39523-39528.

Palmer, J. S., Z. Z. Zhen, C. Hoekstra, N. K. Hayward, P. M. Webb, D. C. Whiteman, N. G. Martin, D. I. Boomsma, D. L. Duffy, and G. W. Montgomery. 2006. Novel variants in growth differentiation factor 9 in mothers of dizygotic twins. J. Clin. Endocrinol. Metab. 91:4713-4716.

Pangas, S. A. and M. M. Matzuk. 2005. The art and artifact of GDF9 activity: Cumulus expansion and the cumulus expansion-enabling factor. Biol. Reprod. 73:582-585.

Pangas, S. A., C. J. Jorgez, and M. M. Matzuk. 2004. Growth differentiation factor 9 regulates expression of the bone morphogenetic protein antagonist gremlin. J. Biol. Chem. 279:32281-32286.

Paulini, F. 2010. Expression of Growth and Differentiation Factor 9 (GDF9) and Bone Morphogenetic Protein 15(BMP15) and Their Effect on In vitro Luteinization of Bovine Granulosa Cells. Masters Dissertation, School of Agronomy and Veterinary Medicine - UnB, Brasília, DF, Brazil.

Peng, J., Q. Li, K. Wigglesworth, A. Rangarajan, C. Kattamuri, R. T. Peterson, J. J. Eppig, T. B. Thompson, and M. M. Matzuk. 2013. Growth differentiation factor 9:bone morphogenetic protein 15 heterodimers are potent regulators of ovarian functions. Proc. Natl. Acad. Sci. USA. 110:E776-785.

Reader, K. L., D. A. Heath, S. Lun, C. J. McIntosh, A. H. Western, R. P. Littlejohn, K. P. McNatty, and J. L. Juengel. 2011. Signalling pathways involved in the cooperative effects of ovine and murine GDF9+BMP15-stimulated thymidine uptake by rat granulosa cells. Reproduction 142:123-131.

Richard, F. J. and M. A. Sirard. 1996. Effects of follicular cells on oocyte maturation. I: Effects of follicular hemisections on bovine oocyte maturation in vitro. Biol. Reprod. 54:16-21.

Sánchez, F. and J. Smitz. 2012. Molecular control of oogenesis. Biochim. Biophys. Acta. 1822:1896-1912.

Shimasaki, S., R. K. Moore, G. F. Erickson, and F. Otsuka. 2003. The role of bone morphogenetic proteins in ovarian function. Reprod. Suppl. 61:323-337.

Shimasaki, S., R. K. Moore, F. Otsuka, and G. F. Erickson. 2004. The bone morphogenetic protein system in mammalian reproduction. Endocr. Rev. 25:72-101.

Silva, J. R. V., R. Van Den Hurk, H. T. A. Van Tol, B. A. J. Roelen, and J. R. Figueiredo. 2005. Expression of growth differentiation factor 9 (GDF9), bone morphogenetic protein 15 (BMP15), and BMP receptors in the ovaries of goats. Mol. Reprod. Dev. 70:11-19.

Silva, J. R. V., R. Van Den Hurk, M. H. T. Matos, R. R. Santos, C. Pessoa, M. O. Moraes, and J. R. Figueiredo. 2004. Influences of FSH and EGF on primordial follicles during in vitro culture of caprine ovarian cortical tissue. Theriogenology 61:1691- 
1704.

Silva, J. R. V., C. C. F. Leitão, and I. R. Brito. 2009. Transforming growth factors $-\beta$ superfamily members and control of folliculogenesis in mammals. Rev. Bras. Reprod. Anim. $33: 149-160$

Silva, J. R. V., M. A. L. Ferreira, S. H. F. Costa, and J. R. Figuereiredo. 2002. Morphological features and control of follicular growth during folliculogenesis in domestic ruminants. Ciência Anim. 12:105-117.

Spicer, L. J., P. Y. Aad, D. Allen, S. Mazerbourg, and A. J. Hsueh. 2006. Growth differentiation factor-9 has divergent effects on proliferation and steroidogenesis of bovine granulosa cells. J. Endocrinol. 189:329-339.

Su, Y. Q., X. Wu, M. J. O’Brien, F. L. Pendola, J. N. Denegre, M. M. Matzuk, and J. J. Eppig. 2004. Synergistic roles of BMP15 and GDF9 in the development and function of the oocytecumulus cell complex in mice: Genetic evidence for an oocytegranulosa cell regulatory loop. Dev. Biol. 276:64-73.

Su, Y.-Q., K. Sugiura, and J. Eppig. 2009. Mouse oocyte control of granulosa cell development and function: Paracrine regulation of cumulus cell metabolism. Semin. Reprod. Med. 27:32-42.

Su, Y.-Q., K. Sugiura, K. Wigglesworth, M. J. O’Brien, J. P. Affourtit, S. Pangas, M. M. Matzuk, and J. J. Eppig. 2008. Oocyte regulation of metabolic cooperativity between mouse cumulus cells and oocytes: BMP15 and GDF9 control cholesterol biosynthesis in cumulus cells. Development 135:111-121

Sutton, M. L., R. B. Gilchrist, and J. G. Thompson. 2003. Effect of in-vivo and in-vitro environments on the metabolism of the cumulus-oocyte complex and its influence on oocyte developmental capacity. Hum. Reprod. Update 9:35-48.

Tanghe, S., A. Van Soom, H. Nauwynck, M. Coryn, and A. De Kruif. 2002. Minireview: Functions of the cumulus oophorus during oocyte maturation, ovulation, and fertilization. Mol. Mol. Reprod. Dev. 61:414-424.

Vanderhyden, B. C. 1996. Oocyte-secreted factros regulate granulosa cell steroidogenesis. Zygote 4:317-321.

Vanderhyden, B. C. and A. M. Tonary. 1995. Differential regulation of progesterone and estradiol production by mouse cumulus and mural granulosa cells by a factor(s) secreted by the oocyte. Biol. Reprod. 53:1243-1250.

Vanderhyden, B. C., E. A. Macdonald, E. Nagyova, and A. Dhawan. 2003. Evaluation of members of the TGFbeta superfamily as candidates for the oocyte factors that control mouse cumulus expansion and steroidogenesis. Reprod. Suppl. 61:55-70
Vitt, U. A. and A. J. Hsueh. 2001. Stage-dependent role of growth differentiation factor-9 in ovarian follicle development. Mol. Cell Endocrinol. 183:171-177.

Vitt, U. A., M. Hayashi, C. Klein, and A. J. Hsueh. 2000a. Growth differentiation factor-9 stimulates proliferation but suppresses the follicle-stimulating hormone-induced differentiation of cultured granulosa cells from small antral and preovulatory rat follicles. Biol. Reprod. 62:370-377.

Vitt, U. A., E. A. McGee, M. Hayashi, and A. J. W. Hsueh. 2000 b. In vivo treatment with GDF-9 stimulates primordial and primary follicle progression and theca cell marker CYP17 in ovaries of immature rats. Endocrinology 141:3814-3820.

Vitt, U. A., S. Mazerbourg, C. Klein, and A. J. W. Hsueh. 2002. Bone morphogenetic protein receptor type II is a receptor for growth differentiation factor-9. Biol. Reprod. 67:473-480.

Webb, R., B. Nicholas, J. G. Gong, B. K. Campbell, C. G. Gutierrez, H. A. Garverick, and D. G. Armstrong. 2003. Mechanisms regulating follicular development and selection of the dominant follicle. Reprod. Suppl. 61:71-90.

Wigglesworth, K., K.-B. Lee, M. J. O’Brien, J. Peng, M. M. Matzuk, and J. J. Eppig. 2013. Bidirectional communication between oocytes and ovarian follicular somatic cells is required for meiotic arrest of mammalian oocytes. Proc. Natl. Acad. Sci. USA. 110:E3723-E3729.

Yan, C., P. Wang, J. DeMayo, F. J. DeMayo, J. A. Elvin, C. Carino, S. V Prasad, S. S. Skinner, B. S. Dunbar, J. L. Dube, A. J. Celeste, and M. M. Matzuk. 2001. Synergistic roles of bone morphogenetic protein 15 and growth differentiation factor 9 in ovarian function. Mol. Endocrinol. 15:854-866.

Yeo, C. X., R. B. Gilchrist, J. G. Thompson, and M. Lane. 2008. Exogenous growth differentiation factor 9 in oocyte maturation media enhances subsequent embryo development and fetal viability in mice. Hum. Reprod. 23:67-73.

Ying, Y., X. M. Liu, A. Marble, K. A. Lawson, and G. Q. Zhao. 2000. Requirement of Bmp8b for the generation of primordial germ cells in the mouse. Mol. Endocrinol. 14:1053-1063.

Yoshino, O., H. E. McMahon, S. Sharma, and S. Shimasaki. 2006. A unique preovulatory expression pattern plays a key role in the physiological functions of BMP-15 in the mouse. Proc. Natl. Acad. Sci. USA. 103:10678-10683.

Young, J. M. and A. S. McNeilly. 2010. Theca: The forgotten cell of the ovarian follicle. Reproduction 140:489-504.

Zhao, H., Y. Qin, E. Kovanci, J. L. Simpson, Z.-J. Chen, and A. Rajkovic. 2007. Analyses of GDF9 mutation in 100 Chinese women with premature ovarian failure. Fertil. Steril. 88:14741476 . 